\title{
REVISTA
}

Revista Educación

ISSN: 0379-7082

ISSN: 2215-2644

revedu@gmail.com

Universidad de Costa Rica

Costa Rica

\section{Teacher Perception about Excessive Amounts of Extracurricular Activities that Interfere with Regular Classes}

\author{
Vindas Carmona, Cinthia Jazmín \\ Revista Educación, vol. 44, núm. 1, 2020 \\ Universidad de Costa Rica, Costa Rica \\ Disponible en: http://www.redalyc.org/articulo.oa?id=44060092010 \\ DOI: https://doi.org/10.15517/revedu.v44i1.34531
}

Teacher Perception about Excessive Amounts of Extracurricular Activities that Interfere with Regular Classes

Esta obra está bajo una Licencia Creative Commons Atribución-NoComercial-SinDerivar 3.0 Internacional. 


\title{
Teacher Perception about Excessive Amounts of Extracurricular Activities that Interfere with Regular Classes
}

Percepción de los educadores respecto a la cantidad excesiva de actividades extracurriculares que interrumpen las
clases regulares

Cinthia Jazmin Vindas Carmona

DOI: https://doi.org/10.15517/revedu.v44i1.34531

Universidad de Costa Rica, Costa Rica

Redalyc: http://www.redalyc.org/articulo.oa?id=44060092010

jazvindas@gmail.com

iD http://orcid.org/0000-0002-9352-1440

Recepción: 21 Enero 2019

Aprobación: 21 Agosto 2019

\begin{abstract}
:
This article addresses teacher perception regarding how excessive amounts of extracurricular activities could interfere with regular lessons and, ultimately, affect student academic performance. A survey probing personal opinions regarding this phenomenon was completed by thirty teachers from public and private primary schools and high schools in the Costa Rican province of Puntarenas. The main objective of this study was not only to determine teacher perception, but also to compare collected data with already existing theory on this subject. Results show that even though some of those activities are relevant in training students to become good citizens and future professionals, an overload of extracurricular activities will negatively impact their achievements and knowledge acquisition.
\end{abstract}

KEYWORDs: Extracurricular Activities, School Calendar, Regular Classes, Academic Performance, Syllabus.

\section{Resumen:}

Este artículo aborda el tema de la percepción de algunos docentes con respecto al exceso de actividades extracurriculares y cómo estas podrían interferir con las lecciones regulares de la agenda escolar y, por ende, el rendimiento académico del estudiante. Se realizó una encuesta a treinta educadores de distintas instituciones educativas públicas y privadas en la provincia de Puntarenas para conocer sus opiniones y también comparar la información recopilada en la encuesta con el material teórico ya existente. De acuerdo con los resultados, aunque muchas de las actividades extracurriculares son relevantes para el desarrollo de los estudiantes como ciudadanos y futuros profesionales, la frecuencia con la cual se realizan puede impactar negativamente el desempeño académico del estudiante $y$, por consecuencia su adquisición de conocimiento.

Palabras clave: Actividades extracurriculares, Calendario escolar, Lecciones regulares, Rendimiento académico, Programa de estudio.

\section{INTRODUCTION}

In the past few years, school schedules have changed considerably with new holidays added to the school calendar, for example. Costa Rican high schools, both public and private, now offer a variety of extracurricular and non-formal educational activities. According to Metsäpelto and Pulkkinen (2014), extracurricular activities (ECA's) are considered to be "one of the influential contexts in which children and youth spend their time" (p. 30). As a result, students spend much of their class time preparing for these types of projects or activities instead of focusing on learning cognitive targets required by the Ministerio de Educación Pública (MEP) syllabus. Examples include celebrations such as Independence Day parades which are held during the school year, and which require students to rehearse during school hours many months before the actual holiday. In addition, some institutions commemorate local or communal beliefs and interests, such as, Halloween, Easter or Christmas, athletic tournaments or contests during school hours. 
These types of activities or celebrations are time-consuming, placing a burden and even hindering classroom teaching and learning.

This study investigates teacher perception about how extracurricular activities (ECA) may be taxing school learning and teachers particularly if they interrupt regular classes. Teacher awareness and concern are probed with regards to this issue as well as their own personal experiences. The study also illustrates how student academic performance may be negatively impacted due to over-scheduling of extracurricular activities. Students also find it difficult to balance their time between academic tasks and extracurricular activities, such as participating in their school's soccer, volleyball, basketball, and other sports teams throughout the year.

In Costa Rica, sports tournaments may last up to two consecutive weeks and even longer. Some others do not have specified nor delimited dates, and for that reason, they take from the very beginning to the end of the academic year. Thus, there is no balance between schoolwork (which has been increasing in complexity) and afterschool activities as well as the number of hours or days they require.

\section{BACKGROUND}

Analysis of prior research and theory demonstrates that most authors tend to favor extracurricular activities and extol its benefits on academic performance, a view that modern authors still maintain (Carmona, Sánchez and Bakieva, 2011; Pozón, 2014; Metsäpelto and Pulkkinen, 2014; Bakoban and Aljarallah, 2015). According to Wilson (2009), "determining the long-lasting effects of extracurricular activities may help parents and educators understand how participation can impact students' development now and in the future" (p.13). It cannot, therefore, be denied that extracurricular activities play an important role in helping students attain their learning objectives. Understanding the repercussions that may result from excessive participation in extracurricular activities may help better prepare teachers, and parents to prevent developmental shortcomings among students.

Authors that have contributed significantly to this area include Wilson (2009) who, in her Master's Thesis, Impact of Extracurricular Activities on Students, emphasizes the advantages of such activities, but adds that overloading students can backlash on their academic performance, stating, "The final assumption is that if students are over-extended, injured or participate in too many activities, it may negatively impact social adjustment, academic success and attendance" (Wilson, 2009, p.15). González (2016) states that "well-directed, non-formal activities" in schools may be effective in attaining positive academic performance objectives while strengthening self-esteem and social skills. Yet, she is quick to question the effectiveness of such programs since they are no guarantee of success and vary according to the context as well as student needs and interests.

Similarly, Laínez, Vilches, Jiménez and Palomar (2010) highlight the importance of participating in school activities outside of the classroom and Molinuevo (2008) explains that activities that extend beyond the walls of the school building have a positive impact on student mental health.

Martinic (2015), who researched time distribution in a group of Latin American schools, emphasized that there was evidence pointing towards a constructive and beneficial relationship between time management and academic success. The more time students spent on learning new concepts and knowledge acquisition, the more effective and long-lasting the results. On the other hand, lost classroom time caused by canceled classes, for example, translates into a loss for the students. Thus, classroom time used for any other activities other than teaching produces no academic gains for the student.

Similarly, Martinic (2015) studies an educational policy in Chile, referred to as the Full School Day Program which is based on the rationale that the longer students attend school, the higher their academic achievement. As a result of the extended school day, students scored 2 to 8 points higher in Language Arts and achieved the 6-point maximum in Mathematics. 
Cerdan-Infantes and Vermeesrsch (as cited in Martinic, 2015) refer to an Uruguayan study which concluded that students who attend classes for eight hours per day are $10 \%$ more likely to pass a course than those who attend only three or four hours daily. An Argentinian study proved that students with frequent absences had lower graduation rates than those with regular attendance (Llach, Adrogué and Gigaglia, 2009). According to the World Bank (as cited in Abadzi, 2009), schools in India characterized by higher academic achievement reported 66 more hours per year of instructional time than lower-performing schools. Thus, although an overload of extracurricular activities may not seem to have a direct result on academic performance, whenever class is cancelled regularly as a result of extracurricular activities, these activities may threaten the learning process, leading to long-term consequences in the student academic performance.

\section{Theoretical Framework}

\section{Extracurricular Activities (ECAs)}

Wilson (2009) defines the term, "extracurricular activities" as, "organized student activities connected with school and usually bearing no academic credit" (p. 8). The word extra has diverging connotations. When a person does more than what they are asked to do, then it is considered be "extra". Extrapolating that definition to an academic context:

The word 'extracurricular' can be broken down into its roots for a literal explanation: extra means outside and curricular refers to all of the work you do in the classroom. So extracurricular activities are just activities that you do outside of class (Barge, 2015, par. 5).

Defining this term may be controversial. Some people tend to think of extracurricular activities as activities taking place outside of the school (Laínez et al., 2010), but it is not precisely what the term means. Metsäpelto and Pulkkinen (2014) agree, affirming that ECAs "refer to adult-supervised activities that are unrelated to the primary curricula, provide opportunities for participants to develop specific skills or knowledge, and take place outside of school hours" (p. 11). Nonetheless, other authors such as Moriana, Alós, Alcalá, Pino, Herruzo and Ruiz (2006) define ECAs as activities that take place in the school environment as a complement for the learner and, generally, under the authority of the institution.

For purposes of this study, the definition to be used for ECA will refer to activities held both 'outside of class' or 'outside of school'. An important aspect to consider in either description is a regular class is interrupted in order to conduct the ECA, teachers will lose valuable classroom time and sacrifice the assigned curriculum.

There is current disagreement about whether extracurricular activities benefit or harm students, given that it is believed by some that extracurricular activities ease the load of responsibilities for both teachers and students. ECAs may also be attractive for students since it allows them to become involved in an activity that differs from their usual routine of classwork.

On the other hand, people consider that an excessive and out of the ordinary amount of activities can be problematic or that many of the assignments are not directly related to the learning process. According to Barge (2015), extracurricular programs may include arts, sports, clubs, employment, personal commitments, and other pursuits which are not directly related to the contents and topics that students must, supposedly, acquire in class. In a study by Pozón (2014), all of the participants agreed that ECAs should take a back seat to academic life, given that their purpose could never surpass classwork instruction and the school syllabus. 


\section{School calendar}

In Costa Rica, the Ministry of Public Education (MEP) is the government body responsible for creating and approving school schedules each year. The school calendar runs from the beginning to the end of the academic year. It includes exam days, non-attendance days and holidays and refers to the average yearly hours that should be devoted to instructional time.

According to the MEP (2006), since 1997, the school term has undergone multiple negotiations between the MEP and representatives of the National Magisterium and, finally agreed on 200 teaching days. The school year runs from February to December and that the school day should not be less than five hours. The Costa Rican educational calendar includes approximately 30 holidays, including Easter week and the midyear break. The school year is divided into three quarters in which students receive a grade for their academic performance in each subject.

Teachers use the school calendar as a guide to plan their lessons during the year (MEP, 2017). Primary and secondary schools are expected to adhere to the lesson plan to the extent possible. Schools may also hold additional local activities that are additional to the school calendar. Problems may arise when unforeseen events, such as natural disasters, bad weather, teacher strikes and other political or local issues interrupt class time and alter the official school calendar. As a result, teachers are not able to accomplish all of the items in the syllabus, creating gaps in student learning.

According to Martinic (2015), some Latin American studies reveal that official assigned teaching hours differ, in fact, from what is truly put into practice in real life. Although, 180 official school days may be scheduled per year, some countries report only 100 productive days and that approximately $50 \%$ of the teaching hours are lost during the school year. Possible causes are due to conflict, long-term public sector strikes, labor or work-related disabilities (medical), and natural disasters, for example.

\section{Regular Lessons}

The term, "Regular Lessons", refers to the number of uninterrupted lessons that students are required to attend within a certain timeframe. In Costa Rica, for example, students are expected to attend 200 days per year of regular classes. In the rest of Latin America, students are required to attend an average number of 800 hours of regular lessons during the school year (Martinic, 2015), a requirement which is not usually met. Martinic (2015) states that students from third world countries in the Americas suffer these consequences since they have less class time and many hours are spent on systematic teaching. In addition, as a result of standardized schedules students miss many regular lessons.

Similarly, Tenti (2010) asserts in The United Nations Educational, Scientific and Cultural Organization's State of the Art that intended instructional time varies significantly from the teaching hours that students truly receive. He also highlights that this is more common in third-world countries which function based on two and even three shifts per day. Consequently, the intended instructional time is not accomplished as originally intended.

In addition to regular class attendance, students must take exams, do classwork, execute projects and attend special assemblies to commemorate holidays. How these activities are distributed impacts the attainment of the objectives planned at the start of the school year. Sacristán (2008) refers to this as the time spent in the classroom under the guidance of a teacher. The duration, contents and assignments are generally identical for all students and the content, basically is that of the planned curriculum. 


\section{Academic Performance}

In Costa Rica, academic performance is primarily based on student test grades. At the end of each unit, term or year, students are assesses according to a number that represents the level attained in the acquisition and production of new knowledge (summative evaluation).

According to the MEP Regulation for Evaluating Learning (MEP, 2009), a student achieves satisfactory academic performance in primary school the first two years of secondary school (seventh through ninth grades) with a final grade of 65 or above. In the tenth and eleventh grades, the passing grade is 70 or above. Academic progress is dependent on a variety of factors, including socioeconomic, psychological, family, and motivational aspects as well as other variables, such as context, repetition, student level/characteristics, gender, age, highest level of schooling attained by parents, class size, source of funding, general culture, and whether the school is a public or private institution (Martinic, 2015).

This study mainly focuses on the impact caused when too many extracurricular activities are scheduled during class time which lead to interruption regular lessons. which, in turn, is detrimental to the future academic success of students. According to Moriana et al. (2006), student activities both within and outside of the school influence the achievement of their educational objectives.

Evidence shows that students who enhance their daily school hours with extracurricular activities tend to obtain better academic performance. In addition, Bamuhair, Farhan, Althubaiti, Rahman, and Al-Kadri (2016) state that "class attendance [also] has a positive impact on academic performance. This relationship suggests that dramatic improvements in average grades and failure rates could be achieved if efforts are made to increase class attendance rates among high school students" (p. 1). Similarly, Arulampalam, Naylor, and Smith (2007) observed 1,322 students during three years and concluded that "that missing class has an adverse effect for 'high capacity' students and that missing $10 \%$ of classes is associated with a 1-2 percentage point grade reduction" (p. 20).

\section{Impact of Irregular Class Attendance on Students and Teachers}

Although extracurricular activities are part of the daily lives of both teachers and students, they are a cause for irregular class attendance. One of the reasons for this is the gradual inclusion of mandatory in-school projects during class time. Teachers must prepare for these projects which use the time that was originally intended to teaching the contents of the curriculum.

As a consequence, an inadequate approach towards lessons or if lessons are missed, lead to negative results. Based on Guleker and Keci (2014) "Missing class is among the causes for academic failure" (p. 961). For example, it may cause a student to receive lower grades since there was not enough time for the teacher to teach the information that the students need to fully understand a subject.

Studies have established direct relationship between the amount of time spent on teaching and its importance to student development. Carroll (as cited in Redd, Boccanfuso, Walker, Princiott, Knewstub and Moore, 2012) shared the premise "that learning at school is dependent on the amount of time that a teacher has available to teach and its relationship to the amount of time a student needs to absorb and process the information" (p. 14).

Redd et al. (2012) analyze extended learning times, and more precisely, the Extended School Day (ESD) schedule that is used as a model by many schools in the United States. This approach reveals how student outcomes relate to attendance. The authors conclude that "the majority of studies (20 out of 27 studies reviewed) found mostly favorable relationships between ESD programs and academic outcomes, while seven had mostly nonsignificant findings" (p. 17). A relationship, therefore exists between length of time and learning. Interruption of regular lessons due to ECAs is an option that provides only marginal benefits 
to student development. Although they may enrich student knowledge in some areas, it is, generally, not commensurate to the contents in the curriculum. An excess of ECAs will eventually overload students with additional work and may to be detrimental instead of beneficial.

\section{Methodological Framework.}

\section{Contributors and Procedure}

A group of thirty teachers were asked to complete a professionally vetted educational survey consisting of twenty-one questions separated into three sections. The surveys were either distributed in person or e-mailed to the respondents. The first section included personal information, age and gender of the respondent. The second section consisted of thirteen closed-ended questions that involved checking a Yes/No response in a blank box. The eight remaining questions were open-ended questions that the respondents could answer freely. The main purpose of the survey was to learn about teacher perception, specifically in Puntarenas, Costa Rica, regarding the excessive amount of extracurricular activities on the school calendar that interrupt regular classes and impact student academic performance

of students.

The respondents included elementary and secondary school teachers, twenty of which were female and ten male, ranging between the ages of 21 to 51, employed either at private or public institutions in the Puntarenas. The rationale behind including elementary and secondary school teachers from private and public schools was to identify if varying perspectives were commensurate with their surroundings. Lastly, we analyzed data collected from completed surveys and compared it with data obtained from our previous literature review.

\section{Analysis of Data and Results}

Undoubtedly, accomplishing too many tasks in a short amount of time is a concern, but the general disregard for this is even more concerning. Including extracurricular activities in the curriculum is perceived as an effort to promote culture, entertain students, motivate them to get involved in the educational process and, to a certain extent, release teachers from their responsibilities. Nevertheless, results show that the outcome is not always a positive one.

When teachers were asked about their knowledge regarding activities scheduled in the scholar calendar, $100 \%$ percent responded positively (Figure 1) which meant that as teachers, they were all completely aware about the subject matter to be studied. 


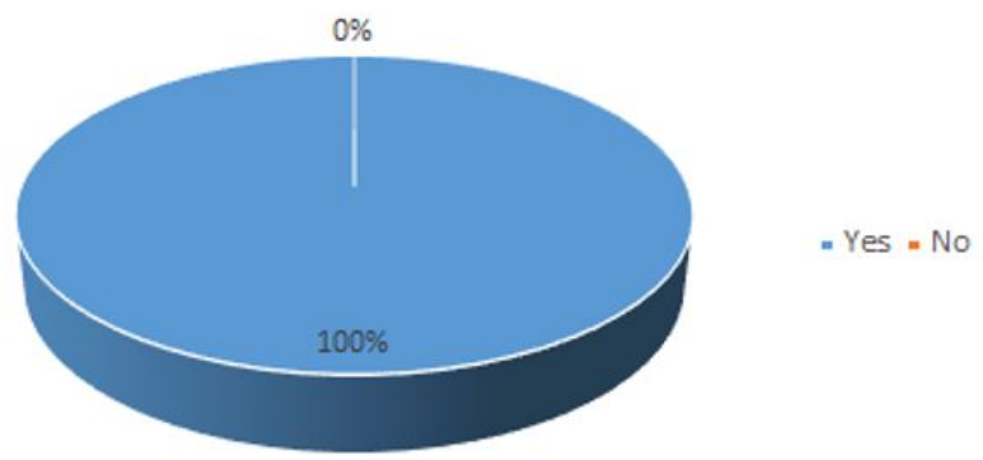

FIGURE 1

Teacher familiarity with official school calendars

Source: Author survey

Based on the survey that we conducted, although a hundred percent of the interviewees stated that they considered extracurricular activities (commemoration of holidays at schools, for example) to be an important aspect of education, most agreed that the amount of these activities was excessive. Ninety-two percent (92\%) of the respondents said less time should be spent on commemorating holidays since it meant having to suspend classes.

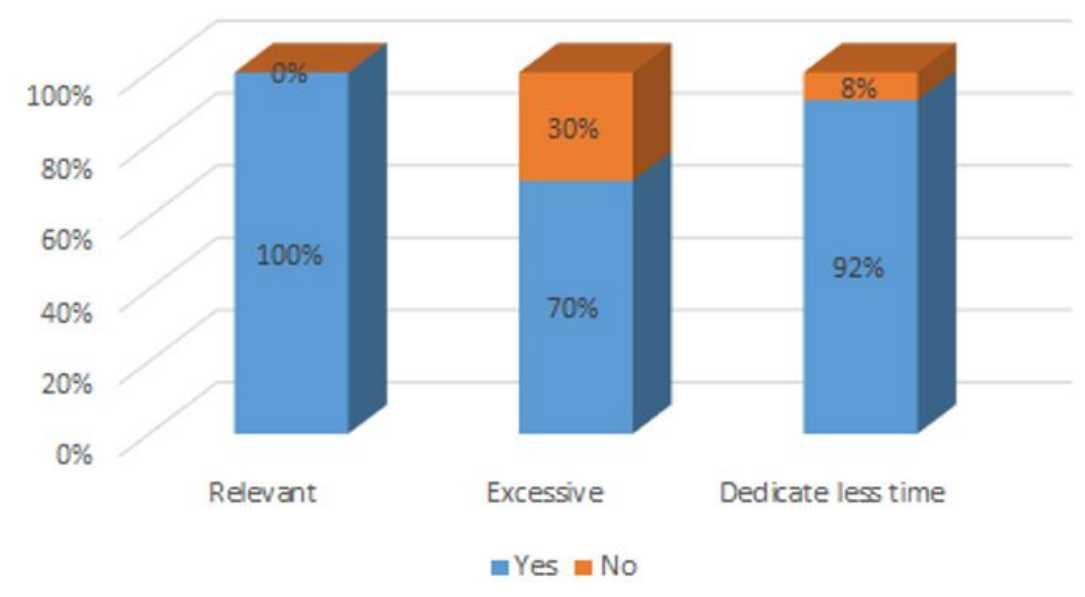

FIGURE 2

Teachers Perception about ECAs

Source: Survey by Author

When interviewees were asked to share their opinions about ECAs ( See Figure 2), they all had similar answers. Most emphasized that they had a positive impact in developing the personal skills of the students. Other advantages voiced included greater interaction with others and awareness of their culture, roots, and society. Nevertheless, they also agreed that programs needed to be better focused in order to avoid wasting time. These results are consistent with Pozón (2014) who stated that teachers tend to disregard the importance of these activities unless they are directly linked to and reinforce an academic learning experience. 
Regarding the disadvantages or negative impact of ECAs on the teaching and learning process, $77 \%$ of the survey respondents stated that interrupting regular classes to hold any other type of activity jeopardizes student acquisition of new knowledge for the following reasons:

1. Disrupt didactic planning. Consequently, students find themselves unable to understand certain topics which were not fully taught. Almost half of the respondents believe that ECAs cause idleness and laziness among students.

2. Restrict teachers, preventing them from providing special needs students with more personalized attention.

3. Delays material in the syllabus from being taught. Lack of time to teach the subject matter properly due to time spent on ECAs causes learning gaps among the students. For example, 77\% of respondents admitted to having to condense or even skip over certain topics, although they did their best to fit them in as requested by the MEP (See Figure 3).

According to Ivars (2008) the top activity that hinders the learning process is lack of time that teachers have available to cover the contents as a result of a teacher conference, teacher-training, and other complementary activities that overlap with the school schedule and interrupt learning during class time.

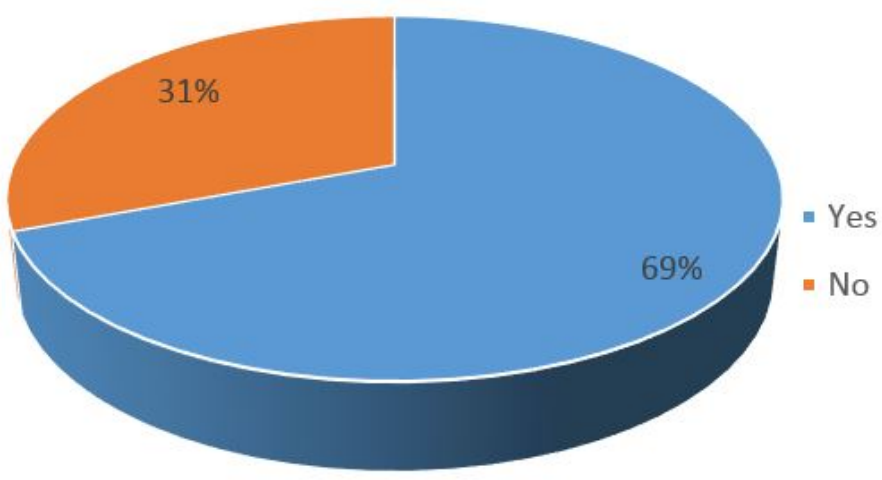

FIGURE 3

Feasible Coverage of Syllabus Content

Source: Survey by Author

Based on the aforementioned findings, $69 \%$ of the survey respondents agree that interrupting classes to allow the teacher to attend administrative activities, such as meetings, conferences, training, workshops, and seminars may negatively impact student performance (See Figure 4). 


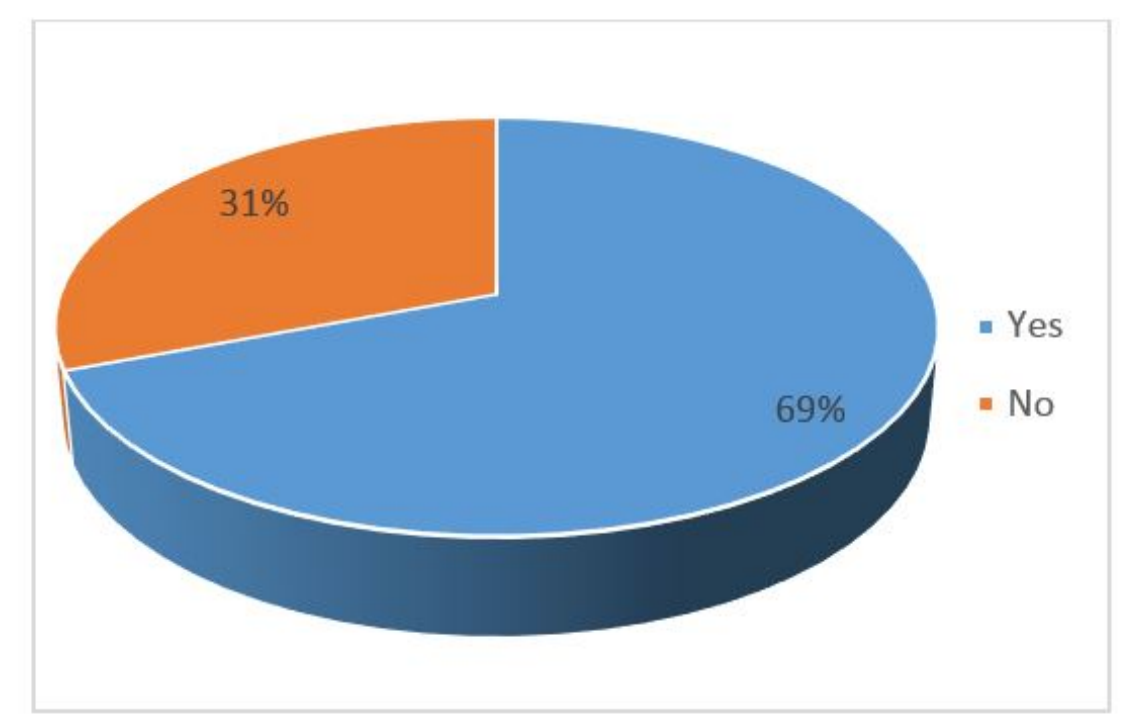

FIGURE 4

Negative Impact on Students as a result of Administrative Factors Source: Survey by Author

It is rather concerning that, in Costa Rica, it is mandatory for students to attend extracurricular commemorative activities, whether they are in agreement or not. Ivars (2008) acknowledges that students are encouraged to participate in such activities, despite the possible associated negative impact on student academic performance and, furthermore, like Pozón (2014), the author adds that participation in these types of ECAs should be chosen freely instead of being mandatory for the student.

In Figure 5, 85\% of the respondents concur that if the same amount of time spent on ECA activities (which interrupt class time) were to be used for teaching lessons in the classroom, student academic performance would improve. Although Moriana et al. (2006) and Carmona et al. (2011) determined that the reasons behind student participation in ECAs was to improve their academic performance, this was true for students who participated in extracurricular activities considered to be academic in nature and related to subjects covered during regular classes. 

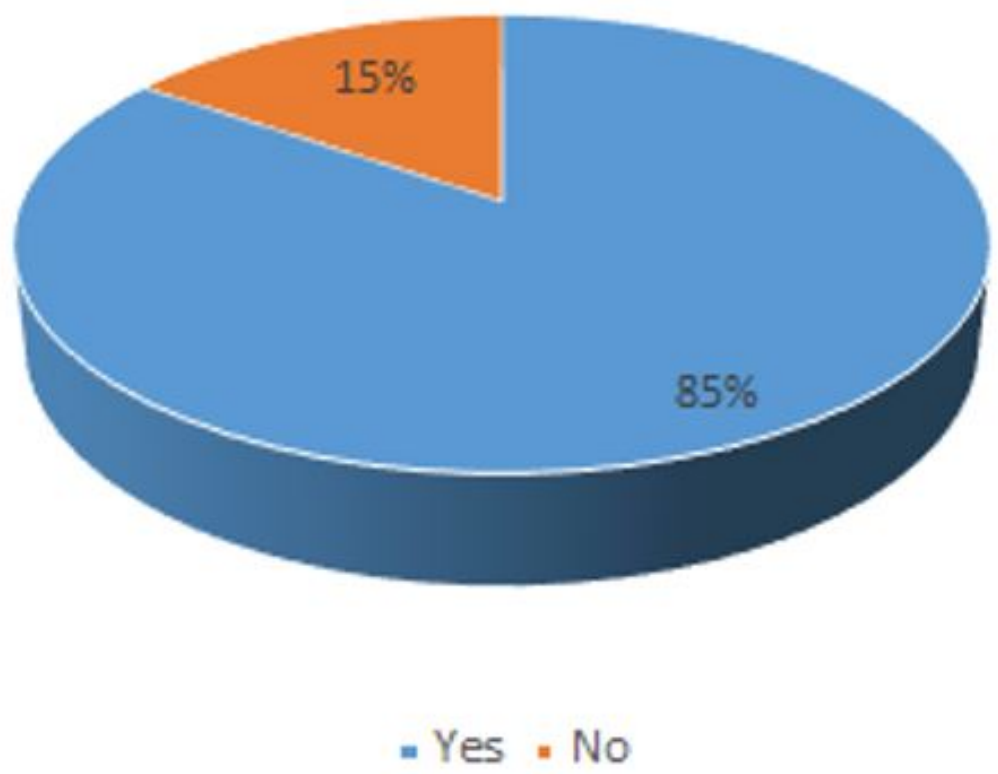

FIGURE 5

More Lesson Time Equals Better Grades

Source: Survey by Author

Another outcome from overloading students and teachers with non-formal activities during regular class time is the associated stress. Teachers may feel frustrated when they do not have enough time to cover all cognitive targets or when they do so in a superficial manner due to the expectation that they must prepare lessons and cover a large variety of other tasks, a situation that, according to the survey respondents, impacts their role as educators, causing mental and physical fatigue. About this, they also affirmed that too many tasks they must accomplish are not even related to their authentic duties as teachers and tutors.

Meador (2019) reports that, "Many teachers arrive early, stay late, and spend part of their weekends working to ensure that they are adequately prepared" (par. 2).

In the case of the students, Driscoll (2011) affirms that they "spend most of their time on campus stressed out. Balancing classes, tests, projects, extracurricular activities, and work...enough to make anyone feel overwhelmed, especially when final exams right around the corner" (par. 1). Laínez et al. (2010) also highlight that when students participate in too many ECAs, they do not study as they should, focus on class and become stressed due to an overload of tasks. Therefore, students may risk prioritizing and spending more time on these type of activities than on those that could benefit their academic performance.

When analyzing teacher perception regarding ECAs that interrupt regular classes, it can be concluded that this is a problem unique to the Costa Rican educational system and one, that at first glance, may not seem to be high priority. However, when considering student success, the survey participants including both primary and secondary public or private school teachers, agree that this situation should be examined more in-depth by the appropriate government authorities to ensure the delivery of good quality education.

This study does not advocate eliminating ECAs from the school calendar altogether, but, rather, aims to shed light on a situation that the educational system has remained invisible, particularly, when students must pay the price for misused class time. 


\section{Conclusions and Recommendations}

Survey data was aligned to data observed in relevant literature and prior studies. ECAs may benefit students if they are well-balanced and have a relevant academic purpose that may help motivate student interest in learning. Somehow, extracurricular activities also ease the burden of both learner and teacher the teacher's burden. Benefits are directly related to cognitive targets in the MEP program which promote integral development. Some ECAs may not generate any type of learning experience and, in some cases, considered unnecessary in educational institutions that are meant to instruct - not entertain.

Research in the field reveals that extracurricular projects are not a problem per se. The problem lies in the excessive amount of time that is lost through ECAs, forcing teachers to skip over or shorten specific subject matter which, in turn, reduces the overall teaching quality. If regular classes were not interrupted by ECAs, student performance would improve considerably as would the quality of Costa Rican education.

Improving education means

Activities that interrupt regular classes should, therefore, be closely examined with regards how useful they are to the academic development of students who must no longer be deprived of vital classroom learning time. The goal is not to eliminate all extracurricular activities from the school curriculum, but, rather, to better adapt them to academic objectives and the surrounding environment. ECAs must be reviewed and reorganized in order to better balance the academic needs of students with recreational and motivational activities outside of the regular classroom that may also reap educational benefits. (See Annex 1 Part 1-2)

\section{ReFERENCIAS}

Abadzi, H. (2009). Instructional Time Loss in Developing Countries: Concepts, Measurement, and Implications. The World Bank Research Observer, 24(2), 267-290. doi: https://doi.org/10.1093/wbro/lkp008

Arulampalam, W., Naylor, R., and Smith, J. (2007). Am I missing something? The effects of absence from class on student performance. Warwick Economics Research Papers, (2), 1-35. Retrieved from https://bit.ly/2aSEGtL

Bakoban, R., and Aljarallah, S. (2015). Extracurricular activities and their effect on the student's grade point average: Statistical study. Academic Journals, 10(20), 2737-2744. doi: https://doi.org/10.5897/ERR2015.2436

Bamuhair, S., Al Farhan, A., Althubaiti, A., Rahman, S., and Al-Kadri, H. (2016). Class attendance and cardiology examination performance: a study in problem-based medical curriculum. International Journal of General Medicine, (2016)9, 1-5. doi: https://doi.org/10.2147/IJGM.S96627

Barge, M. (2015). What Are Extracurricular Activities and Why Do You Need Them? [Blogpost]. Retrieved from ht tps://bit.ly/2JzXn6s

Carmona, C., Sánchez, P., and Bakieva, M. (2011). Actividades Extraescolares y Rendimiento Académico: Diferencias de Autoconcepto y Género. Revista de Investigación Educativa, 29(2), 447-465. Retrieved from https://bit.ly/ 2FCqeUL

Driscoll, E. (31th March, 2011). Stress in College: What Causes it and How to Combat it. FoxBussines. Retrieved from https://fxn.ws/2LoQdms

González, S. (2016). ¿Qué impacto tienen las actividades extraescolares sobre los aprendizajes de los niños y los jóvenes? Barcelona: Fundació Jaume Bofill, Ivàlua

Guleker, R., and Keci, J. (2014). The Effect of Attendance on Academic Performance. Mediterranean Journal of Social Sciences, 5(23), 961-966. doi: https://doi.org/10.5901/mjss.2014.v5n23p961

Ivars, B. (2008). Adaptación de la metodología docente a las necesidades del alumno actual. Alfabetización digital en la licenciatura de periodismo. $A B A C U S$, (5), 1-12. Retrieved from https://abacus.universidadeuropea.es/hand le/11268/3009 
Laínez, B., Vilches, M., Jiménez, J., and Palomar, M. (2010). Importancia de las Actividades Extraescolares en la Educación Secundaria Obligatoria. Revista Digital Eduinnova, (20), 1-10. Retrieved from https://bit.ly/2sFw $\mathrm{q} 8 \mathrm{~h}$

Llach, J., Adrogué, C., and Gigaglia, M. (2009). Do longer school days have enduring educational, ocupational, or income effects? A natural experiment in Buenos Aires, Argentina. Economia Journal,10(2), 1-43. Retrieved from https://bit.ly/2IWqe47

Martinic, S. (2015). El tiempo y el aprendizaje escolar. Revista Brasilera de Educação, 20(61), 479-499. doi: https:// doi.org/10.1590/S1413-24782015206110

Meador, D. (4th May, 2019). Strategies for Teachers: The Power of Preparation and Planning. ThoughtCo. Retrieved from https://bit.ly/2VTIRPt

Metsäpelto, R., and Pulkkinen, L. (2014). The benefits of extracurricular activities for socioemotional behavior and school achievement in middle childhood: An overview of research. Journal for Educational Research Online, 6(3), 10-33. Retrieved from https://bit.ly/2XfKLth

Ministerio de Educación Pública [MEP]. (2006). Elementos de Análisis sobre el tema de los Doscientos días anuales de clase efectiva en el Sistema Educativo Costarricense. San José, Costa Rica: M.E.P. Retrieved from https://bit.ly/ 2FFDYyp

Ministerio de Educación Pública [MEP]. (2009). Reglamento de Evaluación de los Aprendizajes: Evaluación de la Conducta, No 35355. San José, Costa Rica: M.E.P. Retrieved from https://bit.ly/2xlcEka

Ministerio de Educación Pública [MEP]. (2017). Calendario Escolar 2017. San José, Costa Rica: M.E.P.

Molinuevo, B. (2008). Actividades Extraescolares y Salud Mental: Estudio de Su Relación en Población Escolar de Primaria (Doctoral Thesis). Universitat Autónoma de Barcelona, España. Retrieved from https://bit.ly/2X9u PUr

Moriana, J., Alos, F., Alcalá, R., Pino, M., Herruzo, J., and Ruiz, R. (2006). Actividades extraescolares y rendimiento académico en alumnos de Educación Secundaria. Electronic Journal of Research in Educational Pyschology, 4(1), 35-46. Retrieved from http://www.redalyc.org/pdf/2931/293123488002.pdf

Pozón, J. (2014). Los estudiantes universitarios ante las actividades extracurriculares. Revista Andaluza de Ciencias Sociales, (13), 137-150. doi: https://doi.org/10.12795/anduli.2014.i13.08

Redd, Z., Boccanfuso, C., Walker, K., Princiota, D., Knewstub, D., and Moore, K. (2012). Expanding Time for Learning Both Inside and Outside the Classroom: A Review of the Evidence Base. Wisconsin: Child Trends.

Sacristán, J. (2008). El valor del tiempo en educación. Madrid: Morata.

Tenti, E. (Coord). (2010). Estado del arte: Escolaridad primaria y jornada escolar en el contexto internacional. Estudio de casos en Europa y América Latina. Buenos Aires: IIEP

Wilson, N. (2009). Impact of Extracurricular Activities on Students (Master Thesis) University of Wisconsin-Stout, U.S.A. Retrieved from https://bit.ly/2HChBrY

\section{Annex 1. Survey}

Universidad de Costa Rica - Sede del Pacifico Enseñanza del Inglés Trabajo de Investigación: "Percepción de los profesores respecto a la cantidad excesiva de actividades curriculares en el calendario escolar que interrumpen las clases regulares y su impacto en el rendimiento académico en los estudiantes"

El presente instrumento consta de 13 preguntas cerradas y otras 8 abiertas y, tiene como propósito conocer la opinión de los/las docentes de Centros Educativos en el área de Puntarenas, respecto a las numerosas 
actividades extracurriculares (feriados, celebraciones...) que traen consigo la suspensión de muchas clases y cómo esto puede estar influyendo en el rendimiento de los estudiantes.

\title{
I Parte. Información personal.
}

\author{
Edad \\ Género: $\mathrm{F}(\ldots) \mathrm{M}$ \\ Nivel: Primaria \\ Secundaria
}


Cinthia Jazmín Vindas Carmona. Teacher Perception about Excessive Amounts of Extracurricular Activ...

II Parte.

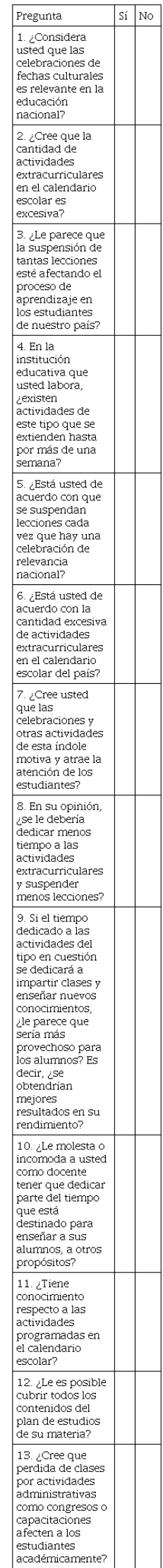




\section{Parte.}

1. ¿De qué forma afecta la excesiva cantidad de actividades extracurriculares tanto en su labor como docente y en el rendimiento académico de los estudiantes?

2. En su opinión, ¿Qué beneficios traen las actividades extracurriculares a los estudiantes?

3. ¿Qué razones podrían ser las causantes de que le dificulte cubrir todos los contenidos del plan de estudios del MEP?

4. ¿Está de acuerdo con las actividades programadas en calendario escolar de la educación costarricense? ¿Por qué?

5. Aparte de las fechas y actividades ya establecidas por el Ministerio de Educación Pública, ¿cuáles otras realizan en el centro educativo para el cual usted labora?

6. ¿Qué opina sobre el tiempo dedicado a la realización de actividades extracurriculares (aparte de las del calendario) en las instituciones educativas del país y de su impacto en el aprendizaje de los alumnos? Por ejemplo, Halloween, torneos deportivos, viajes de campo, excursiones, competiciones artísticas, festivales, desfiles de bandas, entre otros.

7. ¿Cuáles cambios considera que podrían hacerse en el calendario escolar con respecto a las actividades extracurriculares?

8. Si dependiera de usted, ¿cuáles celebraciones u otras actividades similares eliminaría? ¿Por qué?

\section{BY-NC-ND}

